\title{
5 \\ PRACTICAL ACTION, THEORETICAL IMPACTS Aged care and disability services reform in Australia
}

\author{
Mike Woods and David Gilchrist
}

\section{Introduction}

In Western democracies such as Australia, the provision of human services (the care and supports provided to people who fall into specific 'at-risk' cohorts such as the aged or people living with disability) is a central element of the drive to build equity and social cohesion (Frumkin 2002).

In Australia, the consolidation of the concept of the welfare state following World War II was preceded by a half century of initiatives including the development of pensions and the pursuit of welfare through the industrial relations system and parliamentary review. There was similar debate and experimentation in Britain, including publication of the Beveridge Report into social insurance (Beveridge 1942). Constitutional changes in Australia during the mid-1940s empowered the Commonwealth to provide an extended range of income support (including for the unemployed and widows) and benefits (such as for medical and pharmaceutical expenses, child endowment and maternity allowances). This represented a broader acceptance by governments of their responsibility for the provision of human services (Butcher \& Gilchrist 2016). The changes formalised 
many aspects of the almost anti-theoretical approach of policymakers and actors that was recognised as Australian pragmatism and that developed from the time of colonisation (Metin 1977).

Within a decade of the establishment of the welfare state in British-linked Western democracies such as Australia, however, scholarly movements emerged that attacked the fundamental theoretical underpinnings of economic and political science that held sway for the first half of the 20th century at least - namely, institutional theory. Indeed, the primacy of the institution as a vehicle for policy implementation (of which the welfare state was the ultimate exemplar) was undermined by work that took a diametrically opposed view, replacing the institution with the individual as the focus of policy development (Peters 2012).

Much of the subsequent literature dichotomises these two ideas as being polar opposites. ${ }^{1}$ For instance, from the mid-1950s, theoretical schools such as that of public choice (Buchanan 1954) - developed a discourse that elevated the influence of the individual and discounted the influence of the institution. By the 1980s, what had been a primarily scholarly exercise became a political drive reflected in Australia by the advent of neoliberal thinking. In the context of the provision of human services and supports, it emphasised the individual and invoked such ideas as 'mutual obligation' (Mendes 2008).

Based on an analysis of two significant national human services policy reforms in Australia - the restructuring of the provision and funding of aged care services and the introduction of the first national disability services individualised funding scheme - this chapter argues that these two apparently dichotomised theories have been brought together in practice to effect the changes.

We use these two reform processes as a foil to argue that policymakers are seeking to exploit the opportunity inherent in both institutional theory and neoliberal ideas, such as public choice, to influence consumer and service provider behaviour. The objectives include improving individual outcomes and at least stabilising fiscal sustainability by implementing human services delivery and funding arrangements via quasi-market structures.

1 Rhetoric of scholarship. 
This chapter is divided into four sections. In section two we briefly review the theoretical underpinnings of institutional theory and behavioural or individualist - neoliberalism. In section three we describe the broad framework for the delivery of aged care and disability services in Australia and the reforms being implemented in terms of the theoretical framework discussed above, using these two sub-sectors of human service delivery to exemplify our argument. We provide concluding remarks in the final section.

\section{Theoretical underpinnings}

An ongoing discourse of the first four decades of the 20th century grew out of late 19th-century examinations of the economic state of the working poor, and discussion and experimentation with respect to the best course of action aimed at mitigating the extreme effects of poverty and inequity primarily derived from the consequences of the industrial revolution. This discourse culminated in setting aside the liberal tenets of individualism and self-help that were hallmarks of popular 19th-century economic thinking. It was replaced with 'scientifically' developed ideas pertaining to institutional resolutions to the endemic and wicked problems of inequity and poverty (White 2012; Deane 1980). Predominantly, these ideas were developed and promulgated by people who considered themselves the founders of sociology and who believed that institutions were the appropriate vehicle for the implementation of policy and the management of human behaviour (for example, see Webb \& Webb 1965; Tawney 1964).

The popular champions of the move to place the institution at the point of primacy in public policy implementation included Max Weber (1947) from a scholarly perspective and William Beveridge (1942) from a public policy perspective. Beveridge's report Social Insurance and Allied Services set out the framework and logic of the United Kingdom's welfare state that was subsequently implemented through the establishment of such institutions as the National Health Service.

This brief analysis of the development trajectory and basis of institutional theory focuses on the central tenets of this school of thought. In particular, the rule of law is a critical precondition providing the necessary foundation for the creation of a civil society - that is, there is a hierarchy of society and a respect for institutions. Institutions are the lever used to develop, 
guide and manage that society (Peters 2012). Accordingly, structure is considered to drive personal behaviour, shape policy and act as the political frame.

We focus on the two main streams of institutional theory: (1) what might be termed classical institutional theory; and (2) new institutionalism. The former constitutes the original theoretical framework while the latter relates to a revision or revival of institutional theory in response to neoliberal ideas pertaining to individualism such as public choice. Peters (2012) argues that the latter form resulted from a reprise of classical institutional theory that broadened the theory particularly to include informal institutions in order to maintain the centrality of these ideas in the context of the significant advance of neoliberal thinking.

Institutionalism is a normative theoretical framework (Ostrom 2007). Fundamentally, it considers that the institution drives behaviour and that policymakers need to design institutional responses to the wicked problems of human services provision in order to ensure equity of access and outcome. As the 1970s and 1980s wore on, though, the scholarly push to replace institutional theory with neoliberal ideas of individual behaviourism became mainstream. Policymakers argued that individuals, who make preference choices regardless of the nature of the institutions serving them, should be the focus of policy development.

This idea saw a move away from a focus on bureaucratic institutions toward a broader conception of collective action (Denhardt 2011) - which incidentally led thinking away from the idea of government responsibility (the classical welfare state mentality) to collective responsibility in which government is one actor amongst a number. Indeed, in relation to human services provision in Australia, by the mid-1990s public choice theory was the driver of much public policy (Barraket 2008).

This policy framework manifested itself in a number of fundamental and important ways. For instance, the idea of mutual obligation in relation to human service provision and financial support was established at this time. ${ }^{2}$ Additionally, as these services are increasingly provided in Australia by not-for-profit and charitable organisations, governments began

2 Perhaps re-established is a better phrase as this idea was a significant part of the 19th-century liberal thought that was displaced by institutional theory in the 20 th century. 
to utilise market-based procurement regimes, including competitive tendering and the use of the term 'client' to describe service users (Alford \& O'Flynn 2012).

While, at a policy development level, the acceptance of such neoliberal ideas was almost universal, a number of scholars did not accept the turn that theory and practice had taken. They warned (and continue to warn) of the unintended consequences manifesting as a result particularly of quasi-market funding rationing systems and the primacy of the individual, essentially arguing that 'a rising tide [does not] lift all boats' (Stiglitz 2013: 1; see also, Rainnie et al. 2012; Davidson 2011; Van Slyke 2007; Barraket 2008; McGregor-Lowndes 2008).

Importantly for this chapter, by the second decade of the 21 st century, many policymakers in Australia sought to establish quasi-market environments intended to empower consumers and create incentives for providers, while creating institutional structures that sought to correct for market failures. The former aimed to enable the individual service user to make choices about from whom they sourced their services and how they received them, and to own the decision and demand provider performance. Providers were encouraged to respond to 'market signals' thus delivering a better outcome more efficiently. The institutional reforms aimed to improve information and transparency so that service users could make informed choices, to ensure there were sound safety nets for individuals and enforceable quality standards and to instigate alternative interventions in 'thin' markets.

In effect, many policymakers made use of a combination of institutional theory and neoliberalism to elicit the policy outcomes that best served the interests of the community as a whole. In the next section, we examine this phenomenon by way of two policy examples being implemented in Australia.

\section{Reform - aged care and disability services}

In Australia, two significant human services reforms are underway relating to the provision of publicly funded aged care services and disability supports and care services - respectively referred to herein as aged care and disability services. In this section, we briefly describe the background to 
these reforms; examine the framework for reform, including aspects that demonstrate a reliance on both institutional theory and neoliberalism; and discuss the key features of both new structures.

While reform is being carried out in these two sub-sectors contemporaneously, government is, in fact, implementing differing systems for each. Whereas there is a common resort to neoliberalism underpinning both, the way in which institutional theory is drawn on takes a different form in each, with disability services reforms intended to result in greater transparency and accountability through reliance on governance bodies that are independent of the ministerial-departmental nexus that dominates aged care.

Partly this is to do with the historical policy settings that moulded each sub-sector, effectively forcing the Commonwealth government to drive change from different starting positions. Partly it is to do with the fact that aged care, and residential aged care in particular, has historically been the domain of the Commonwealth government, while the provision of disability services has been the domain of the sub-national jurisdictions making up the Australian federation, with each of those jurisdictions adopting different policies and programs. Finally, it is also partly to do with the fact that aged care is fundamentally an elderly and end-of-life care and support system while disability services form a whole-of-life care and support system.

Broadly, these reforms are being carried out by the Commonwealth government, with the involvement of sub-national jurisdictions where necessary - particularly for disability services. In terms of institutions, the reforms impact not-for-profit and for-profit contracted service providers, government departments and regulators at various levels. In terms of policy development, however, a critical element in the reform process is the role of the Australian Productivity Commission (hereafter, the Commission). It has investigated and reported upon aspects of aged care for over a decade, disability services more recently, and the role of the notfor-profit and charitable sectors in Australia as fundamental institutions that support civil society (Productivity Commission 2010). 


\section{Background to the aged care and disability care reforms}

The current reforms of aged care and disability services have similar origins. Following the election of the federal Labor government in 2007, the Productivity Commission was issued with two terms of reference to undertake broad-ranging public inquiries into the policies, programs, regulations, funding and service quality of both sectors.

The Commission is an independent policy research and advisory body established under an Act of the Commonwealth parliament. It operates at arm's length from government and conducts open and transparent public inquiries and research to inform itself and develop recommendations that are in turn provided to government and, importantly, are published. It accepts its inquiry briefs from the Commonwealth government, however, and those briefs can prioritise, emphasise or curtail investigations in relation to specific areas of interest. As such, there is a tension between the nature of the brief being given and the interests of independent and transparent research and reporting practice. In this respect, the Commission draws on the independence inherent in its legislated powers, when it considers it necessary, to 'also make recommendations in the report on any matters relevant to the matter referred' (Commonwealth of Australia 1998 s.11(4)).

In the case of aged care, the Commonwealth government gave the Commission broad and open-ended terms of reference, asking it to develop options to redesign and reform Australia's aged care system and to recommend a transition path to a new system (Productivity Commission 2011a). More detailed terms of reference were also set out to provide a framework for the inquiry.

In the case of the inquiry into disability services, the terms of reference required the Commission to examine a range of options and approaches for the provision of long-term care and support for people with profound disability (Productivity Commission 2011b). The Commission was required to examine a social insurance model on a no-fault basis, reflecting the shared risk of disability across the population, as well as other options that provided incentives to focus investment in early intervention, as an adjunct to, or substitute for, an insurance model. 
The Productivity Commission's report (2011a) Caring for Older Australians documented a range of problems in the aged care sector. The issues included high levels of unmet demand; a lack of continuity of care as a person's needs increased; inconsistent pricing of the different types and levels of care; limited incentives for service providers to become more efficient, improve quality or respond to consumer demand; workforce shortages; complex, overlapping and costly regulations; insufficient independence of the complaint-handling process from the Commonwealth Department of Health; and incomplete and overlapping responsibilities within and between jurisdictions.

The disability care story was much the same. The Productivity Commission's report (2011b) Disability Care and Support concluded that most families and individuals could not adequately prepare for the risk and financial impact of significant disability. The costs of lifetime care could be so substantial for individual households that the risks and costs needed to be pooled across the community. The Commission found that the disability support system was underfunded, unfair, fragmented and inefficient, and gave people living with disability little choice and no certainty of access to appropriate supports. There was no nationally consistent level of care and support and the stresses on the system were growing, resulting in rising costs for individual households and all governments.

\section{Governance of major policy review and reform}

Rationales for government involvement in aged care and disability services exist in the national discourse. These include equity of access to appropriate care, the protection of vulnerable consumers and the correction of market failures such as gaps in the provision of information about available services and, in the case of disability, the probability of an individual having a disability being low but the lifelong costs that could ensue being potentially catastrophic (Gilchrist 2017; Knight \& Gilchrist 2015). As such, evidence-based and objective governance over the development, examination and consideration of policy was critical to identifying measures that would provide access to appropriate care and support for service users, incentives for service providers to improve efficiency and effectiveness, and the achievement of greater value for money and fiscal sustainability for taxpayers. 
The Commission's institutional processes are well suited to undertaking major policy reviews. The three organisational design pillars of the Commission are that:

1. it is independent (it is ruled by commissioners who are appointed for up to five years and whose independence is protected by law)

2. it conducts its policy inquiries in an open and transparent manner

3. its guiding principle is improvement of the wellbeing of the community as a whole - it acts in the public interest.

Appropriately, the Commission's role does not extend to final decisionmaking or implementation. This separation of functions is an important element of sound governance design. Accordingly, its recommendations on the reform of aged care and disability services, both published in 2011, were subject to scrutiny by the central departments - as well as by the two departments primarily responsible for aged care (Department of Health) and welfare services (Department of Social Services). In both cases, the government also undertook extensive consultation processes and developed the final reform packages that were agreed to by the cabinet. The Aged Care (Living Longer Living Better) Act 2013 and the National Disability Insurance Scheme Act 2013 were subsequently passed.

Following government agreement to these major policy reforms, government service delivery departments and agencies commenced implementation and undertook ongoing monitoring and revision of the detail of the policy and its programs. Different governance arrangements have evolved for aged care and disability services, but each draws on institutional theory and neoliberalism. These elements are explored further in the following subsections.

\section{Governance of service delivery management and accountability}

This section examines and contrasts the governance model adopted for aged care, which is administered by the Commonwealth government through the Department of Health, with that of disability services, which is administered jointly between the Commonwealth and participating sub-national governments and a newly created independent institution, the National Disability Insurance Agency (NDIA). The two governance models bring with them differences in arrangements for the oversight of 
policy and administration, funding and quality control. Notwithstanding, each establishes the institutional framework necessary for the governance of the publicly funded services, and at the same time establishes a quasimarket environment within which services are demanded and supplied.

\section{Aged care: A departmental model within one level of government}

The funding and regulation of aged care is largely the responsibility of the Commonwealth government via the Department of Health, which reports directly to the Minister for Aged Care. The Aged Care Act 1997 and related legislation provides the legal basis for the department's actions and requires the department to report annually on its operations. There are no transparency or accountability requirements for publication of the minister's directions to the department. The department closely manages the performance of all aspects of the aged care programs, from operational policy and regulation of service supply and delivery, to funding and a high level of direct involvement in the regulation of quality.

Although there are several formal non-departmental bodies that contribute advice in relation to policy, management and funding, the Department of Health is involved in their operations, especially by providing the staff for their secretariats. As noted below, only the quality regulator operates as a fully independent statutory authority, but even it works jointly with the department, which is responsible for the enforcement of quality standards through the licensing of providers.

The services provided to service users, either in their own homes or in residential aged care facilities, are delivered by not-for-profit organisations or for-profit businesses (with a small number of facilities still run by sub-national governments) rather than directly by the Department of Health. Aged care subsidies are largely funded from the annual budgets of the Commonwealth government. User co-payments (both capital and operating) are made by services users according to the cost of the services being delivered and their capacity to pay.

Services delivered in users' own homes have been reformed through the introduction of consumer-directed care, with funding being provided to users and providers having to compete for business. Supply-side limits still apply to both home care and to care delivered in residential facilities. 


\section{Disability services: An independent agency model across two levels of government}

Prior to the recent reforms, each sub-national government provided for the care and supports for people with disability within its jurisdiction. This resulted in there being considerable diversity across jurisdictions in the types of care available for comparable levels of disability, the quantity and quality of services and the amount of funding made available to providers. As such, among other things, people with disability could not move jurisdictions with any assurance that they would receive, or be able to afford, the supports that they required.

All governments have now committed to a National Disability Strategy that aims to support people with disability, to improve their lives as well as the lives of their families and carers, and to provide leadership for a community-wide shift in attitudes towards disability.

Within the National Disability Strategy, the National Disability Insurance Scheme (NDIS) has been established to enact a fundamental change to how supports and services for people with permanent and severe disability are funded and delivered across Australia. The total number of people with disability being supported by the NDIS is limited by the eligibility criteria. Accordingly, considerable responsibility under the broader strategy remains with both sub-national and national health, education and community service agencies. The NDIS is an important part of the system, but it is not the whole system.

As explained further below, the governance structure for the NDIS is different to that for aged care. NDIS is managed by an independent agency that reports to the Council of Ministers from the Commonwealth and state/territory governments. The Commonwealth Department of Social Services coordinates Commonwealth policy advising and budgeting, but has no direct role in funding or regulating disability services.

The NDIS can pay for supports, housing modification, transport assistance, assistance to seek and sustain employment and other services that pass the test of being 'reasonable and necessary'. This means that the services and supports are relevant to a person's disability and are necessary for them to be able to live an ordinary life and achieve their goals. Services are delivered by approved providers who compete for customers in a quasi-market. Local area coordinators for the NDIS can also assist people with disability to access mainstream community services such as 
medical care and education, and to participate in community activities and services. ${ }^{3}$ Sub-national jurisdictions continue to directly support those with disability who are not eligible for NDIS assistance.

\section{Oversight of policy and administration}

\section{Aged care}

Given the extensive nature of the aged care reforms and the decadelong timeframe in which they are being progressively implemented, the Minister for Aged Care and the Department of Health ${ }^{4}$ closely monitor this implementation phase. The cost of the scheme, however, and aged care issues that may impact on broader policy settings such as taxation and the age pension, also attract the attention of the central departments.

The Department of Health has considerable internal capacity to undertake a policy-monitoring role. It has also established an Aged Care Sector Committee ${ }^{5}$ comprising members appointed from the major stakeholder groups such as consumers, large for-profit and not-for-profit providers, aged care worker organisations and the department. The department's staff provide the secretariat for the committee.

The committee's Aged Care Roadmap offered advice to the minister on the future directions for aged care. This committee is the only broadly based institution capable of holding the government to account for its overall management of the aged care system; however, its communiqués issued after every meeting (averaging four per year) make only brief mention of matters discussed and do not report on the outcomes of its deliberations on those matters. The terms of reference of the committee require that members respect the confidentiality of the committee proceedings.

Policy monitoring and review was entrenched in the legislation that gave legal force to the reforms. There is a requirement in the Aged Care (Living Longer Living Better) Act that the minister initiate an independent

3 These arrangements are yet to be effectively implemented and, as can be expected with such a complex and large policy rollout, there have been identified many significant issues in the context of examining the intention and the reality; for example, see Gilchrist (2017).

4 For information relating to the structural components of this department, see 'Aged Care Sector Committee', Ageing and Aged Care, Department of Health, Australian Government, agedcare.health. gov.au/aged-care-reform/aged-care-sector-committee.

5 For information pertaining to this committee, see 'Terms of reference: Aged Care Sector Committee', Ageing and Aged Care, Department of Health, Australian Government, agedcare.health. gov.au/aged-care-reform/aged-care-sector-committee/terms-of-reference-aged-care-sector-committee. 
review of the operation of the reforms provided for under the Act after the first three years of their implementation. The minister appointed the chair of the Aged Care Sector Committee as the independent reviewer and the department provided the research secretariat.

The government released the report of the legislated review in 2017. The review concluded that the reforms it examined (being a subset of the total reform agenda and excluding major issues such as funding and quality regulation) had successfully progressed the achievement of a consumerdriven and sustainable system, but that there was further progress to be made (Department of Health 2017a, 2017b).

The aged care sector's stakeholders, including consumer groups, providers, workforce organisations and health professionals have established the National Aged Care Alliance, ${ }^{6}$ which has played a long-term constructive role in improving aged care. It was particularly effective in contributing to the Productivity Commission's 2010-11 inquiry and in subsequently assisting both sides of politics in the parliament to accept the reform framework.

\section{Disability services}

Responsibility for disability services policy and administration for those who are eligible for NDIS support is shared between the Commonwealth and sub-national governments in accordance with the various bilateral agreements discussed above. A new governance framework is being developed as part of the establishment of the NDIS. ${ }^{7}$

A ministerial council - the Standing Council on Disability Reform - is the peak level of the strategy as a whole. ${ }^{8}$ It comprises the Commonwealth Minister for Social Services and state/territory ministers with disability and treasury portfolios, as well as a representative from the Australian Local Government Association. Building on the framework developed by

6 For information pertaining to this organisation, see National Aged Care Alliance, www.naca.asn. $\mathrm{au} /$.

7 As of mid-2017, bilateral agreements with a number of sub-national governments were being negotiated and uncertainty exists with respect to those agreements currently in place. Inevitably, experience of the processes in practice will inform reflection on the original agreements.

8 For information pertaining to this council, see 'Disability Reform Council', Disability and Carers, Department of Social Services, Australian Government, www.dss.gov.au/our-responsibilities/ disability-and-carers/programmes-services/government-international/disability-reform-council. 
the Productivity Commission (2011a), the council ensures the strategy reforms are implemented through an intergovernmental National Disability Agreement. ${ }^{9}$

The National Disability Agreement specifies that all participating governments have joint responsibility for a range of functions: developing national policy and reform directions, as well as funding and pursuing research and providing data that improves the evidence base for policy and reform. The agreement also provides that each jurisdiction can, where appropriate, invest in initiatives to support nationally agreed policy priorities, in consultation with other levels of government. The enabling legislation for the NDIS also required a review to be undertaken after two years of operation of the scheme.

Under the agreement, the Commonwealth is responsible for the provision of employment services for people with disability; income support targeted to the needs of people with disability, their families and carers; funding for the sub-jurisdictional governments to assist them in meeting their obligations under the scheme; and funding disability services for the elderly.

The participating sub-national governments are responsible for providing non-employment disability services; funding and regulating basic community care services, except for the elderly who have a disability; and funding community care packages and residential aged care delivered under Commonwealth aged care programs (again, except for the cohort aged over 65, which is a Commonwealth responsibility. There are, however, mitigating provisions for circumstances when people with disability enter the NDIS prior to turning 65 years of age).

Additional bilateral agreements deal with various matters including, in the case of the Northern Territory, the issue of provider of last resort and, for Western Australia, in relation to the state retaining a more significant decision-making capacity. As described above, however, the rollout of the new arrangements has highlighted significant issues with these agreements.

9 Information pertaining to this agreement is available here: 'National agreements', Council on Federal Financial Relations, Australia, www.federalfinancialrelations.gov.au/content/national_agreements.aspx. 
The NDIS started with a small number of trials in several jurisdictions and is being progressively rolled out across the nation over a three-year period. Oversight is undertaken by the Standing Council on Disability Reform. The Commonwealth minister is responsible for administering the National Disability Insurance Scheme Act and exercises statutory powers with the agreement of states and territories, including a power to make the rules for the scheme and direct the newly created NDIA.

The NDIA is an independent statutory authority that was established under the NDIS legislation, rather than as a function of a ministerial department as occurs with aged care. It is governed by a board of directors that is responsible for the efficient and effective performance of the functions of the NDIA and for determining the strategies and policies of the agency. The NDIA reports to the Commonwealth Minister for Social Services as well as the intergovernmental Council of Ministers, and therefore sits within the Commonwealth minister's 'portfolio'. As noted earlier, the Department of Social Services is the 'portfolio' department but has no direct role in NDIS funding or regulation.

The NDIA produces annual reports of its operations together with quarterly reports updating the public on the scheme's rollout. The Commonwealth minister may give directions as well as general strategic advice to the board provided it is in writing and has been agreed to by all participating jurisdictions. To ensure transparency and ministerial accountability, ministerial directions must be published in the NDIA's annual reports.

The Act provides for the appointment of an independent advisory council ${ }^{10}$ to advise the board. The council is predominantly made up of people with disability and some carers of people with disability. In effect, the council provides a formal dedicated consumer voice to advise on the operation of the scheme. In contrast to the Aged Care Sector Committee, the disability governance model enforces greater transparency and accountability. The board of the agency is required to consider and respond to all advice from the independent advisory council and to inform the Standing Council on Disability Reform of the actions it is taking.

10 Information pertaining to this council can be found at 'IAC', NDIS, Department of Human Services, Australian Government, www.ndis.gov.au/about-us/governance/IAC. 


\section{Funding}

\section{Aged care}

Government subsidies for services delivered to eligible service users are funded directly from the budget of the Australian Government's Department of Health. Service users are subject to a means test and make financial contributions commensurate with their capacity to pay. Consumer contributions are also subject to annual and lifetime self-funding limits, reflecting a social insurance principle, with the government meeting full costs once those limits have been reached.

The government's Aged Care Financing Authority (ACFA) ${ }^{11}$ has no funding role but, rather, monitors the financial performance of the aged care system and publishes an annual report on the system's operation. The authority's annual report states: '[its] role is to provide independent, transparent advice to the Australian Government on funding and financial issues in the aged care sector' (ACFA 2017: 20). In effect, the authority is a committee of independent persons and representatives of significant stakeholders that is funded by the department and supported by departmental staff. The minister can request the authority to monitor and report on specific issues relating to the financial performance of the aged care programs such as changes to means-testing arrangements and accommodation payment changes.

Another institution established to regulate certain financial issues in aged care is the Aged Care Pricing Commissioner. This statutory office holder is supported by staff employed by the department. The functions of the commissioner include granting approval, where warranted, to providers who wish to charge capital payments for aged care accommodation that are above a maximum amount set by the minister, and to approve schedules of fees for a range of services that are of a considerably higher standard or scope than is required to be provided under the funded program. These are important risk-mitigating constraints in a quasi-market-based system, given the vulnerability of many consumers of residential aged care and the fact that the service users are ultimately exposed to the supply-side risk of providers failing or otherwise exiting the market. In those instances, the department works closely with other providers with the aim of supporting the elderly who are affected by the closure of a facility.

11 See Aged Care Financing Authority (2016). 
The level (and cost) of community care delivered in service users' own homes is determined by Aged Care Assessment Teams based on the needs of the person. These teams are funded by the Commonwealth and comprise professional health workers such as doctors, nurses, social workers and occupational therapists. The level of co-contribution by a person deemed eligible for government-subsidised care is assessed according to their income and wealth. Under the quasi-market consumer-directed care reforms, the service user can choose from competing service providers to 'purchase' services from one or more providers, and can change the services and the providers. A user's needs can also be reassessed as their circumstances change. The government protects fiscal sustainability by capping the number of community care packages available at any one time.

For care in residential aged care facilities, the government subsidises the service providers directly and maintains caps on demand (the number of care places) and supply (the number of bed licences issued to providers). This significantly constrains the benefits of market competition in residential care, though the government is committed to removing supplyside constraints and introducing consumer-directed care in the future.

To improve the information available to service users, so that they can exercise their progressively increasing market power, the government has established the My Aged Care website and requires service providers to make up-to-date market information available to service users. This represents a bringing together of institutional and neoliberal approaches to reform to benefit empowered consumers and to elicit more competitive behaviour by providers.

\section{Disability services}

Funding arrangements for the disability scheme in 2017 reflected the transition from pilot trials to the scheme's progressive nationwide rollout. They are complex due to the nature of disability services themselves and of the agreements in place. The Commonwealth makes National Disability Specific Purpose Payments to the sub-national jurisdictions in order to meet its contribution to the NDIS, while these jurisdictions continue to fund the original system as it is gradually replaced. As the scheme becomes fully operational in each jurisdiction, Commonwealth payments will be redirected to the NDIA. 
Disability funding is governed by the intergovernmental National Disability Agreement and the National Partnership Agreement on Transitioning Responsibilities for Aged Care and Disability Services. The NDIA holds all NDIS funds contributed by the Commonwealth and sub-national jurisdictions in a single pool, administers assessments of eligibility and access by participants to the NDIS and approves the payment of individualised support packages. The NDIA's annual report must contain an actuarial statement as to the financial sustainability of the scheme together with any risks to that sustainability and estimates of the future costs of the NDIS.

Assistance from the NDIS is not means tested and has no impact on a person's eligibility for income support such as the disability support pension and carer's allowance. Individuals are required to exhaust private insurance cover prior to accessing NDIS funds.

The NDIA has developed a price list that includes individual service elements grouped together as bundles that can be accessed by eligible service users (Gilchrist 2017). Service users are expected to co-create a care plan with the NDIA with reference to the price list. Once the plan is activated, service users can choose services from competing registered providers. In this way, the NDIS is intended to employ quasi-market principles with incentives to influence service provider behaviour to emphasise the interests of service users. While this neoliberal funding arrangement may well solicit certain outcomes, it is intended that quasimarket behaviour is tempered by the institutions that surround the system, including the NDIA and quality control institutions.

\section{Quality control}

\section{Aged care}

One of the central elements of performance accountability within the aged care system relates to the quality and safety of the services being delivered to service users. This is especially important given that the client group are some of the most frail and vulnerable in society, with many having limited cognitive functioning. Indeed, approximately half of all residents in aged care residential facilities have a diagnosis of dementia, and many have other impairments and little financial security. 
To this end, the Commonwealth government has employed an institutional approach by establishing an independent Australian Aged Care Quality Agency under its own Act, with the power to employ its own staff. The Act and its delegated legislation - the Quality Agency Principles 2013 - sets out the obligations with which approved aged care providers must comply. ${ }^{12}$

This agency is supported by an Aged Care Quality Advisory Council that provides advice to the agency on its functions and operations. The advisory council gives essential advice on safety and compliance so as to help align the quality agenda with community expectations.

But even in this sensitive area, there is a lack of clarity of roles and separation of powers. The government has, instead, created dual administration of quality control by the independent agency and by the department. They both have roles in monitoring the compliance of aged care service providers to the quality standards. Where noncompliance is identified, it is the department that assesses the performance of providers and takes appropriate regulatory action, including revoking a provider's approval to deliver services when their standards of care have been found to be particularly poor.

High-profile failures in the regulation of quality in aged care have prompted the government to commission a public review in 2017. The resulting report of the Review of National Aged Care Quality Regulatory Processes was released late in that year. In the words of the reviewers:

Our consultations and research highlighted the need for better coordination of regulatory functions, expanded intelligencegathering capacity and a better system for sharing information on provider performance with the public and aged care service providers, to promote service improvement. We have also recommended changes to accreditation, compliance monitoring and complaints-handling processes to make them more responsive to emerging issues with care quality. (Department of Health 2017b: ii)

12 The functions of this agency have been incorporated into the Aged Care Quality and Safety Commission (see www.agedcarequality.gov.au). 
The government has also created the role of a minister-appointed statutory office holder, the Aged Care Complaints Commissioner, under the Aged Care Act. The role was promoted as creating complaint-handling arrangements independent from the department. ${ }^{13}$ The staff of the commissioner are departmental staff.

An advocacy scheme for service users, their families and carers has also been established. This provides them with free, confidential and independent advice on matters relating to aged care and support. It is an important adjunct in helping this vulnerable group to resolve their concerns in circumstances in which they often feel powerless and confused.

\section{Disability care}

A core component of NDIS performance management and accountability is the quality of the services being delivered to people with disability. Service users bear supply-side risk in that they are directly impacted by market failure where service providers fail.

The core document is the NDIS Quality and Safeguarding Framework, which is designed to ensure high-quality supports and services delivered in safe environments for all people with disability who are participating in the scheme. ${ }^{14}$ The framework was endorsed by the Council of Australian Governments in 2016 and publicly released by the Disability Reform Council in 2017. The framework was developed in consultation with stakeholders, including people with disability, carers, providers and peak bodies. Public consultation helped to inform the final framework.

The framework includes the following new national functions: a code of conduct; provider registration, including quality assurance; a complainthandling system; investigation and enforcement; and nationally consistent worker screening. The code of conduct will be overseen by the new NDIS Quality and Safeguards Commission, which was announced by the Commonwealth Government in 2017 and funded in the 2017-18 Budget. The commission will have powers to enforce action where providers or workers have engaged in unacceptable behaviours.

13 See Aged Care Quality and Safety Commission: www.agedcarequality.gov.au/.

14 'NDIS Quality and Safeguards Commission', Disability and Carers, NDIS, Department of Social Services, Australian Government, www.dss.gov.au/ndisqualitysafeguards. 
An additional and important private institution, which is a significant contributor to the disability services infrastructure, is National Disability Services. This industry peak body has a crucial role in responding to regulatory, funding and quality issues on behalf of the service provider sector.

\section{Concluding remarks}

The advent and implementation of significant reform in the funding and delivery of aged care and disability services in Australia is multifaceted, time consuming and challenging for governments, providers and service users. These are complex, crucial and universal services. Policymakers have considered that neoliberal theories, such as public choice, can be employed to design systems to empower service users with choice and control and create a quasi-market arrangement with embedded incentives for providers to deliver consumer-oriented services with higher quality and lower costs.

A principle aim is to elicit better value for money outcomes for the service users and taxpayers more generally. The benefits derived from quasimarket response behaviours by service providers are also seen as important. Essentially, if the provider is to be successful it is in the provider's interest to respond to the quasi-market signals.

Nonetheless, consistent with institutional theory, institutions have been needed to protect the vulnerability of consumers and correct for market failures, such as by overcoming information asymmetry, improving transparency and intervening in thin markets. A number of institutions and associated government program and regulatory interventions have proven critical in the administration, oversight and evaluation of the policy frameworks. They influence the behaviour of service providers by setting rules relating to funding, quality, service content and service planning.

They also impact behaviour via the requirements for transparency and accountability of governance and the collaboration of institutions and, in the case of disability services, the various bilateral agreements that exist between sub-national and national governments. The latter impact a number of issues that are peripheral to the policy arrangements, but are nevertheless important, such as the impact of oversubscription. 
Within the ambit of institutional theory, there has been considerable divergence of approach, with the aged care framework being heavily reliant on a ministerial-departmental nexus while disability services are administered through more independent and clearly delineated institutions, with greater transparency and accountability. While this divergence has arisen in part from the different histories of the two frameworks (the long dominant role of the Commonwealth in aged care and the dominance of the states and territories in disability services until very recently), it is now opportune to reflect upon the merits of the two approaches and to consider what might be 'best practice'.

In both service areas, there exist formal private institutions - called peak bodies - that act as conduits for information, feedback and the exchange of expertise in the implementation of new policy. Provider peak bodies also exert influence on the way their members deliver services.

The research focus of this chapter demonstrates the utility and purpose of applying multiple theoretical frameworks. The two case studies illustrate that the employment of a neoliberal strategy of quasi-market systems and public choice, which aims to empower service users and give service providers incentives to improve efficiency, effectiveness and responsiveness to consumer demand, is being tempered by resort to institutional theory. The latter is based on control by institutions focused on administering the provision of funding and service rules, correcting market failures and enforcing quality standards.

Future research could investigate the extent to which a multiple-theory implementation framework is effective. It may also investigate the degree to which either institutional theory or neoliberal theories impact differentially on scheme performance, and whether either of the two forms of institutional theory deliver the greater public good. That is, does the combination work and, if so, is it critical or does one school of thought dominate the other in terms of driving service provider performance and service user outcomes?

Overall, the complexity inherent in the provision of human services emphasises the importance of such studies in terms of ensuring the policy framework generates the desired outcomes from the point of view of service users who are, after all, at risk and dependent on these service systems as well as the overall public good. 


\section{References}

Aged Care Financing Authority 2016, Fourth Report on the Funding and Financing of the Aged Care Sector, Department of Health, Commonwealth of Australia, Canberra, www.health.gov.au/committees-and-groups/aged-care-financingauthority-acfa.

- 2017, Fifth Report on the Funding and Financing of the Aged Care Sector, Department of Health, Commonwealth of Australia, Canberra, agedcare. health.gov.au/reform/aged-care-financing-authority/2017-report-on-thefunding-and-financing-of-the-aged-care-industry.

Alford, JL \& O’Flynn, J 2012, Rethinking Public Service Delivery: Managing with External Providers, Palgrave Macmillan, London.

Barraket, J (ed) 2008, Strategic Issues for the Not-For-Profit Sector, UNSW Press, Sydney.

Beveridge, W 1942, Inter-departmental Committee on Social Insurance and Allied Services, HMSO, Great Britain.

Buchanan, JM 1954, 'Individual choice in voting and the market', Journal of Political Economy, vol 62, pp 334-43, doi.org/10.1086/257538.

Butcher, J 2015, 'Australian sub-national compacts with the not-for-profit sector: pathways to cross-sector cooperation', in J Wanna (ed), New Accountabilities, New Challenges, ANU Press, Canberra, doi.org/10.22459/ NANC.04.2015.10.

Butcher, JR \& Gilchrist, DJ 2016, 'Introduction', in JR Butcher \& DJ Gilchrist (eds), The Three Sector Solution: Delivering Public Policy in Collaboration with Not-For-Profits and Business, ANU Press, Canberra, doi.org/10.22459/ TSS.07.2016.01.

Commonwealth of Australia 1998, Productivity Commission Act, 1998, doi.org/ 10.25291/VR/1998-4-VR-459.

Davidson, B 2011, 'Contestability in human services markets', Journal of Australian Political Economy, no 68, pp 213-39.

Deane, P 1980, The Evolution of Economic Ideas, Modern Cambridge Economics, Cambridge University Press, London.

Denhardt, RB 2011, Theories of Public Organization, 6th edn, Wadsworth Cengage Learning, London. 
Department of Health 2016, 2015-16 Report of the Operation of the Aged Care Act 1997, Australian Government, Canberra, gen-agedcaredata.gov. $\mathrm{au} /$ Resources/Reports-and-Publications/2016/December/2015\%E2\% 80 \%9316-Report-on-the-Operation-of-the-Aged-Care-A.

_ 2017a, Legislated Review of Aged Care 2017, Australian Government, Canberra, agedcare.health.gov.au/legislated-review-of-aged-care-2017-report.

_ 2017b, Review of National Aged Care Quality Regulatory Processes, agedcare. health.gov.au/quality/review-of-national-aged-care-quality-regulatoryprocesses-report.

Economic Audit Committee 2009, Putting the Public First: Partnering with the Community and Business to Deliver Outcomes, Report to the Government of Western Australian, Perth.

Frumkin, P 2002, On Being Nonprofit: A Conceptual and Policy Primer, Harvard University Press, London, doi.org/10.4159/9780674037403.

Galbraith, JK 1952, American Capitalism: The Concept of Countervailing Power, Houghton Mifflin Company, Boston.

Gilchrist, DJ 2017, Person Centred Planning within the NDIS: Current Limitations - Prospective Opportunities, report for the Independent Centre for Not-ForProfit Research, Perth.

Knight, PA \& Gilchrist, DJ 2015, 2014 Evaluation of the Sustainable Funding and Contracting with the Not-For-Profit Sector Initiatives and Associated Procurement Reforms, Government of Western Australia, Perth.

March, JG \& Olsen, JP 1984, 'The new institutionalism: organisational factors in political life', American Political Science Review, vol 78, no 3, pp 734-49, doi.org/10.2307/1961840.

McGregor-Lowndes, M 2008, 'Is there something better than partnership?', in J Barraket, Strategic Issues for the Not-For-Profit Sector, UNSW Press, Sydney.

Mendes, P 2008, Australia's Welfare Wars Revisited: The Players, The Politics and the Ideologies, UNSW Press, Sydney.

Metin, A 1977 (1901), Socialism without Doctrine, R Ward (trans), Alternative Publishing Co-operative Ltd, Chippendale.

Office of the Auditor General Western Australia 2000, A Means to an End: Contracting Not-For-Profit Organisations for The Delivery of Community Services, audit.wa.gov.au/wp-content/uploads/2013/05/report2000_03.pdf. 
Ostrom, E 2007, 'Institutional rational choice: an assessment of the institutional analysis and development framework', in PA Sabatier (ed), Theories of the Policy Process, 2nd edn, Westview Press, Cambridge.

Peters, BG 2012, Institutional Theory in Political Science: The 'New Institutionalism', 2nd edn, The Continuum International Publishing Group, New York.

Productivity Commission 2010, Contribution of the Australian Not-For-Profit Sector, Research Report, Canberra.

_ 2011a, Caring for Older Australians, report no 53, Final Inquiry Report, Canberra, www.pc.gov.au/inquiries/completed/aged-care/report/aged-carevolume1.pdf.

- 2011b, Disability Care and Support, report no 54, Final Inquiry Report, Canberra, www.pc.gov.au/inquiries/completed/disability-support/report/ disability-support-volume1.pdf.

Rainnie, SF, Gilchrist DJ \& Morris, CL 2012, 'Putting the public first? Restructuring the West Australian Human Services Sector', International Journal of Employment Studies, vol 20, no 1, pp 104-25.

Salamon, LM 1995, Partners in Public Service: Government - Nonprofit Relations in the Modern Welfare State, The Johns Hopkins University Press, Baltimore.

Stiglitz, J 2013, The price of inequality: how today's divided society endangers our future, Penguin, London.

Tawney, RH 1964, Equality, Unwin Books, London.

Van Slyke, DM 2007, 'Agents or stewards: using theory to understand the government-nonprofit social service contracting relationship', Journal of Public Administration Research and Theory, vol 17, no 2, pp 157-87, doi.org/ 10.1093/jopart/mul012.

Webb, S \& Webb, B 1965 (1894), Industrial Democracy, Augustus M Kelly, New York.

Weber, M 1947, The Theory of Social and Economic Organization, AM Henderson \& T Parsons (trans), The Free Press, London.

White, LH 2012, The Clash of Economic Ideas: The Great Policy Debates and Experiments of the Last Hundred Years, Cambridge University Press, London, doi.org/10.1017/CBO9780511998218.

Wilkins, P \& Gilchrist, DJ 2016, 'Accountability for the public policy contribution of not-for-profit organisations: who is accountable to whom and for what?', in R Pablo Guerrero \& P Wilkins (eds), Doing Good?: Private Actors, Evaluation and Public Value (Comparative Policy Evaluation), Transaction Publishing, doi.org/10.4324/9780203793008-6. 
This text is taken from Designing Governance Structures for Performance and Accountability: Developments in Australia and Greater China, edited by Andrew Podger, Tsai-tsu Su, John Wanna, Hon S. Chan and Meili Niu, published 2020 by ANU Press, The Australian National University, Canberra, Australia.

doi.org/10.22459/DGSPA.2020.05 